\title{
A Methodological Approach to Selecting a Location for a Waste Disposal Terminal for Vessels on the Section of the Pan-European Waterway Corridor VII in the Republic of Serbia
}

\author{
Boško Josimović $^{1}$, Marina Ilić ${ }^{2} \&$ Ljubiša Bezbradica ${ }^{1}$ \\ ${ }^{1}$ Institute of Architecture and Urban \& Spatial Planning of Serbia, Europe \\ ${ }^{2}$ Faculty of Ecology and Environment, Union University, Serbia \\ Correspondence: Boško Josimović, Institute of Architecture and Urban \& Spatial Planning of Serbia, Bulevar \\ kralja Aleksandra 73, Belgrade, Serbia. Tel: 381-11-3207-326. E-mail address: bosko@iaus.ac.rs
}

Received: September 14, 2016

Accepted: September 29, 2016

Online Published: November 7, 2016

doi:10.5539/eer.v6n2p14

URL: http://dx.doi.org/10.5539/eer.v6n2p14

\begin{abstract}
The section of the Pan-European Corridor VII waterway flowing through Serbia is of exceptional international significance, as well as significance to the Republic of Serbia, both in the domains of transport and of environmental protection. In this part of the Pan-European Corridor VII waterway, there is development of both passenger and freight traffic without an established system of control and management of solid waste and wastewater from vessels, which directly threatens the environment, as well as the safety of traffic and people. The crews of international and domestic vessels are faced with the problem of disposing of solid waste, waste oil and waste water, due to the lack of adequate waste terminals in this section of waterway corridor VII (The Danube River). For this reason, the construction of a waste terminal is a priority and an unavoidable necessity as a starting point for establishing a sustainable system of managing waste from vessels in the Republic of Serbia. This paper presents a methodological approach for selecting an optimal location for the construction of such a terminal in the city of Belgrade, capital of Serbia (a case study). The method of multi-criteria evaluation of potential locations was used, as well as the method of evaluating various locations under different scenarios. The specificity of the method used can be seen in the selection of criteria for comparative evaluation of the potential locations, as well as in the evaluation of the potential sites under different scenarios and with weight categories based on the PROMETHEE method. The results presented in this paper make it possible for decision makers to consider different aspects and scenarios when selecting the most appropriate location for the terminal, whilst taking into account the international standards and principles governing this field in the European Union.
\end{abstract}

Keywords: multi-criteria evaluation, selection of a location, terminal for waste from vessels

\section{Introduction}

On its way from the Black Forest in Germany to the Black Sea, the Danube is 2,845 km long and it connects ten countries (Austria, Bulgaria, Croatia, Hungary, Moldova, Germany, Romania, Serbia, Slovakia and Ukraine), making it one of the most important European waterways. The flow of the Danube through Serbia is $588 \mathrm{~km}$ long, of which $137 \mathrm{~km}$ is a section shared between Serbia and Croatia and $229 \mathrm{~km}$ is a section shared between Serbia and Romania. The Danube is categorized as an international waterway by the Convention on the regime of Navigation on the Danube River (Official Gazette of the FPRY, no. 8/49, Official Gazette of the FRY, International Agreements, no. 6/98). As Corridor VII it is an important route, especially after the opening of the Rhine-Main-Danube waterway (1992). The Danube connects the Black Sea with the industrial centers of Western Europe and the port of Rotterdam.

With the intensification of the development of international navigation and navigation in the Republic of Serbia over recent years, issues related to environmental protection when using waterways have become more and more prominent. In this context, effective mechanisms for the collection and disposal of waste generated by vessels are particularly important. However, although from the Co-WANDA report from 2014 it can be seen that in Romania, Croatia, Hungary, Slovakia and Austria, these mechanisms have already been established (Figure 1 terminal network for the collection of waste from vessels in the countries through which the Danube flows), in Serbia no system of managing waste from vessels has been established. As a consequence, the Danube and its 
valuable ecosystems on the territory of Serbia are endangered. There are no organized services for the collection of waste materials from vessels, nor are there any procedures for the management of hazardous waste materials which result from the use of floating vessels. For these reasons, it is considered that there is a strong likelihood of uncontrolled discharges of wastewater from both domestic and international vessels into the Danube River in the section that flows through Serbia. Due to the absence of a terminal for receiving waste from boats, or rather, the lack of services of this kind, the development of uncontrolled discharge from international vessels into the Danube is highly likely, precisely in the section that flows through Serbia. In this sense, pollution of the environment through the direct or indirect discharge of substances into rivers can have devastating effects on the habitats of flora and fauna. Pollution can threaten the living conditions in the river and threaten human health, but it can also interfere with activities related to river transport, fishing, tourism and the like. In particular, pollution can cause a deterioration in the functional quality of the river water and decrease the attractiveness of the river environment.

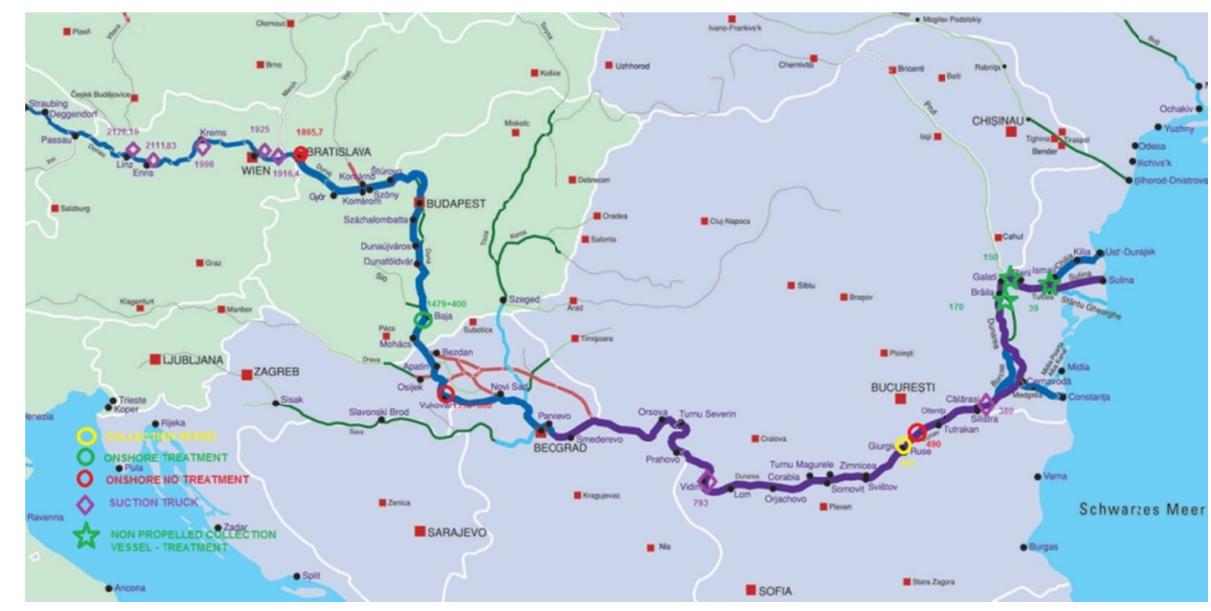

Figure 1. The existing network of terminals for the collection of waste from vessels on the Danube River (Source: Co-WANDA Report, 2014)

These problems suggest that in Serbia there are currently no minimum conditions for the adequate respect of the protection of the environment and human health. For these reasons, the need for a systemic approach to the question of waste substances from vessels has arisen, in order to create conditions for the construction of a specialized terminal and the establishment of control systems, secure unloading, separation, storage, recycling, treatment and eventual disposal of solid and liquid waste materials from vessels. Obligation also comes from the fact that the Republic of Serbia is a signatory to the Convention on solving the problem of hazardous waste (which includes waste from vessels) at an international level, as well as it being an active member of the Danube and the Sava Commissions.

A significant step towards solving the above problems in Serbia is the adoption of the Strategy of development of water transport of the Republic of Serbia from 2015 to 2025 (Official Gazette RS, No. 3/2015). This document gives the basic directions for the development of water transport and infrastructure at the national level, and points to the need for the management of waste from vessels in accordance with the regulations governing waste management.

In addition, the Directive on ports, 2000/59/EC, from the European Parliament, referring to facilities for receiving waste and cargo residues generated on board ships, establishes the obligation for taking care of waste materials in ports arising from the operation of ship systems, as well as the obligation to report to the port authorities the amount of waste materials that are found in at least $25 \%$ of the vessels entering the port, and the obligation for stimulating the surrender of waste materials to the care of the ports.

For all these reasons it is necessary to establish a network of facilities for depositing waste from boats in Serbia, especially in Belgrade as the trade and tourist center, with the highest frequency of vessels expected in the section of the Danube that flows through Serbia. That includes the construction of a terminal for waste materials from vessels in Belgrade.

This paper presents a methodological approach to the selection of a location for a future terminal for waste from 
vessels, the results of which were used in order to make a decision on the most suitable location.

\section{Methodological Framework}

The subject of this paper is the application of the Multi-criteria Evaluation (MCE) method (Josimović et al, 2015) in the selection of a location for a terminal for the disposal and treatment of waste from boats. The MCE method, developed in the early 1970s, is now considered a well-developed scientific field, supported by abundant references (Ananda and Heralth, 2009; Figueira et al., 2005; Kangas and Kangas, 2005). When first developed, MCE was characterised by the methodological principle of multi-criteria decision-making (MCDM) with little or no participatory mechanisms included (Zionts, 1979; Zionts and Wallenius, 1976). The primary objective was to elicit clear preferences from a decision maker and then solve a well-structured problem by means of mathematical algorithms (e.g., to design an engine taking into account its power, weight, and efficiency).

Progressively, the ideas of procedural rationality (Simon, 1976) and the constructive or creative approach (Roy, 1985) led to the development of the multi-criteria decision aid (MCDA), in which the quality of the decision-making process became central. Research started to point out the need to include public participation in MCE (Banville et al., 1998; De Marchi et al., 2000; Proctor, 2004), thus fostering the emergence of participatory multi-criteria evaluation (PMCE) (Banville et al., 1998; Proctor and Drechsler, 2006) and social multi-criteria evaluation (SMCE) (Munda, 2005, 2008). In such a context, appropriate deliberation is a prerequisite to ensuring a quality outcome. Nowadays, the MCE method is often recommended as a convenient support in the decision-making process because of its capacity to point out in many ways multiple alternatives of development on the basis of assessing criteria related to the environment and socioeconomic aspects of sustainable development. (CL:AIRE, 2011; Linkov et al, 2006; Rosén et al, 2009, 2013; Sparrevik et al, 2011).

In the context of the methodological approach of the multi-criteria evaluation of potential locations for a terminal for waste from vessels, or the selection of any location for waste materials, two procedures are applied:

1. simple addition of the values obtained for a potential location in relation to the defined evaluation criteria and

2. multiplication of the values obtained with the importance values (weight values).

The first steps in evaluating potential locations is the easiest, and it has very few requirements. By simply adding the score obtained for each individual criterion, the most favorable score is obtained. The assessment of locations in this case does not have different scenarios that could be of great help to decision makers.

The other procedure is more complicated and different scenarios can be used in it. For example, if the criteria for locating the terminal are classified into a number of groups, then the same number of scenarios are considered as there are groups of criteria. In the first scenario, the criteria from one group are favoured as the most important, in the second scenario the most important criteria are from another group, and so on. As the last option, the situation is considered in which the groups of criteria are multiplied by the same score of importance, without favouring any individual of the groups of criteria. By presenting the different scenarios in a synthesis table it becomes easy to see which locations for which scenarios are the most favorable. An example of this type of approach is the PROMETHEE (Preference Ranking Organisation Method for Enrichment Evaluation) method (Brans, Vincke, 1984). The primary advantage of this approach is that it gives decision makers a clear idea about which potential location is the most favorable if the criteria from one particular group are evaluated as the most important (environmental or economic or spatial etc.), and which is the most favorable if the basic groups of criteria are treated equally. The application of the different scenarios is based on the PROMETHEE method (Behzadiana et al, 2010).

A combination of these methodological approaches provides the decision makers with more options on the basis of which it is possible to make an optimal decision, which was the case in the specific example of selecting a location for a terminal for waste from vessels in Belgrade.

\section{Case study: Selecting the Location for a Terminal for Waste from Vessels in Belgrade, the Capital of Serbia}

The choice of location for the construction of a terminal for waste from vessels in the city of Belgrade, the capital of Serbia, was carried out in two phases: phase I - identifying potential locations suitable for the terminal, and phase II - multi-criteria evaluation of the potential locations for the terminal.

\subsection{Identification of Macro Locations Potentially Suitable for the Terminal}

Identifying potential locations involved selecting a certain number of locations that meet the basic preconditions for the terminal, and those are: 
$>$ having an appropriately defined use of the land in planning documentation (elimination criteria);

$>$ accessibility of the location from the waterway;

$>$ having a large enough area of undeveloped land;

$>$ the available infrastructure of the location (with a priority for transport infrastructure).

The starting point for identifying potential locations for the terminal was the existing planning/urban planning documents, that is, the General Urban Plan (GUP) of Belgrade until 2021 (Official Gazette of the City of Belgrade no. 25/05, 34/07, 63/09 and 70/14). In this plan, the areas were determined which, in terms of their function, are compatible with that of a terminal for waste from boats. In the Plan, these areas are defined as space for municipal services. The zones in the Belgrade GUP intended for municipal services provided the framework within which four potential locations (hereinafter referred to as: PL) were determined for the phase of multi-criteria evaluation (Figure 2).

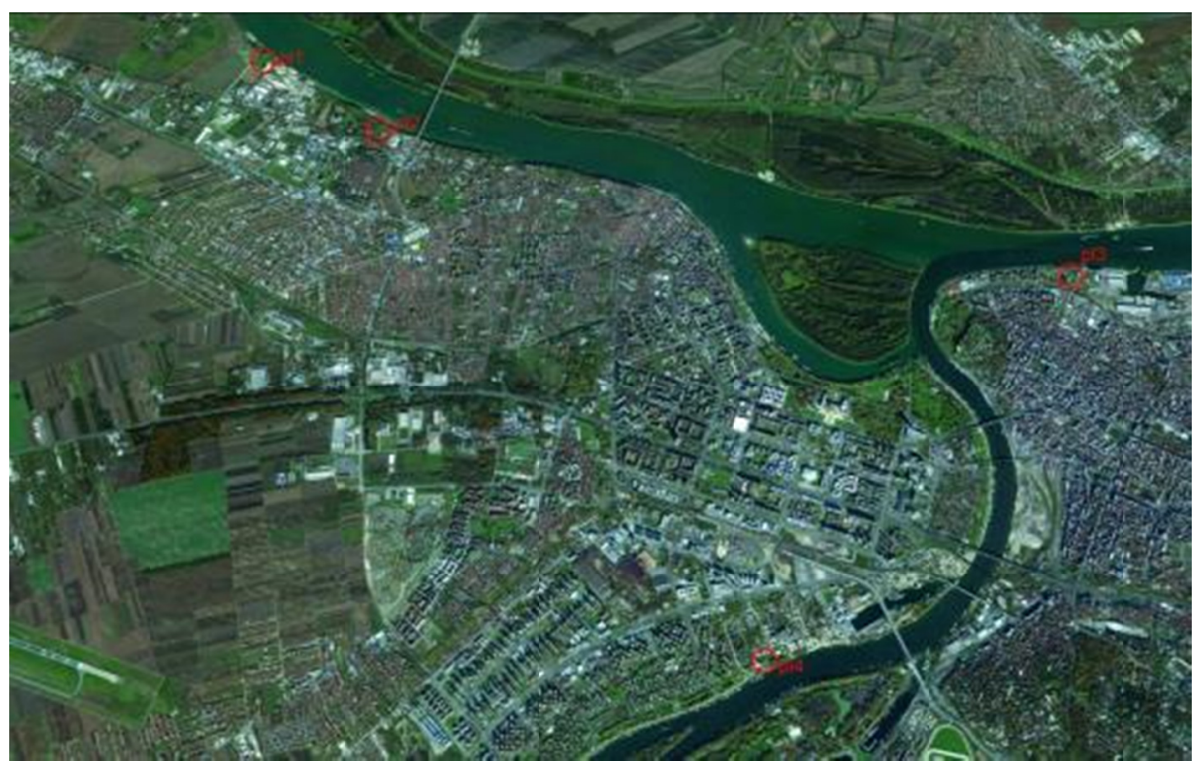

Figure 2. Potential locations for the construction of a terminal for waste materials from vessels (zones envisaged by the GUP of Belgrade for municipal services)

PL1 and PL2 are located on the Danube, in the municipality of Zemun (Figure 2). Both locations are, according to the GUP of Belgrade, intended for municipal services, and PL1 was developed by the Plan for the detailed regulation of the commercial zone of upper Zemun in Zemun, zones 3 and 4 (Official Gazette of the City of Belgrade, number 14/05).

PL1 covers an unbuilt area of approximately 150 acres, and it is situated in the space between the Knauf company and a gravel pit on one side, and the Directorate for the National Reference Laboratory of the Ministry of Agriculture and Environmental Protection on the other side. At this location there are no bank revetments, and there is no mooring for vessels.

The space covered by PL2 is an unbuilt area of approximately 70 acres. However, at this location there are individual residential buildings with unknown status in terms of the necessary construction and other permits. In addition, in the immediate vicinity of the site are the Zemun Mining Institute and the Govedji Brod settlement. At this location there are no bank revetments, and there is no mooring for vessels.

PL3 is situated on the Danube River, in the municipality of Stari Grad in the area of the Port of Belgrade (Figure 2). According to the GUP of Belgrade, the priority for the developing the urban unity of the Port of Belgrade is to bring together all of its different functions, alongside the transformation of any inadequate contents and space to become a quality environment. The area has good infrastructure. Location 3 was developed by a Plan detailing the regulation of the Ada Huja area (zone A) in the municipalities of Stari Grad and Palilula (Official Gazette of Belgrade, number 17/12). According to this plan the proposed location is situated in an area envisaged for municipal services infrastructure. The unbuilt space in PL 3 conditionally consists of two parts, of which the part nearer to the Danube has an area of approximately 50 acres, and the other section is about 50 acres (a total of approximately 100 acres). At this location there are bank revetments, as well as the possibility of mooring 
vessels.

PL4 is the only one of the nominated locations that is situated on the Sava River, in the municipality of New Belgrade (Figure 2). As with the previous three nominated sites, this one is also envisaged by the GUP Belgrade to be for municipal services. PL 4 has an unbuilt area of approximately 45 acres. On one side of this potential location is the New Belgrade district heating complex, and on the other side is the New Belgrade block 70a. At this location there are no bank revetments, and there is no mooring for vessels.

Below is a detailed comparative multi-criteria evaluation of the potential locations, primarily in terms of the defined capacity of the terminal and the economic feasibility of the necessary interventions in the area, with consideration of all of the other implications (strategic, social, environmental, etc.). It was inevitable that all relevant institutions and decision makers would be included in this process, in order to select the location for the terminal as soon as possible and avoid any potential spatial conflict.

\subsection{Multi-Criteria Evaluation of Potential Locations for the Terminal}

This Phase II involves the use of the method of comparative multi-criteria evaluation of the potential locations carried out by means of a few basic steps:

$>$ defining the criteria for the evaluation of potential locations,

$>$ determining the weight factors and grouping the criteria into weight categories,

$>$ multi-criteria evaluation of potential locations according to the weight categories,

$>$ evaluation of the potential locations according to different scenarios.

\subsubsection{Defining the Criteria for Evaluating the Potential Locations}

Defining the criteria for determining the location of the terminal is an important methodological step. In practice, two basic groups of criteria are most commonly used.

The first group is that of the elimination criteria which are used in the initial phase of the process of selecting the location for the terminal. The elimination criteria are defined in relation to the actual situation, represented by the restriction criteria. Some of the elimination criteria can be: the planned use of the space, distance from the natural elements of the space, distance from the anthropogenic elements of the space (infrastructure, settlements, protected cultural objects, etc.), and so on. The areas that do not need to be analyzed further are distinguished according to the elimination criteria. For the elimination phase, a single criterion method is generally used, which was the case here. Namely, the elimination criterion in this particular case was "planning documents defining the appropriate use of the land" (in this case for public utilities), together with the fact that all other possible elimination criteria were taken into account in the preparation of the planning/urban planning document that defined such a purpose.

The other group of criteria includes those on the basis of which evaluation of the potential locations will be carried out in an equal manner. The criteria for evaluating the locations can be classified into several groups. These are usually sets of criteria that cover the different implications of the planned project on the environment, and they are:

$>$ ecological or environmental criteria,

$>$ socio-economic, social or spatial criteria, and

$>$ technical and operational criteria (which usually contain certain economic, spatial and environmental criteria).

Any variation of the group of basic indicators is possible. After selecting the relevant criteria, a particularly sensitive and important step in the process of site selection is to define the value of the scale on the basis of which individual criteria are assessed (evaluated, scored). Each criterion is given a corresponding weighted value which is determined on the basis of expert assessment and the evaluation of participants in the process of selecting a location for the terminal. It is usual to use a system of quantitative assessment (e.g. scores ranging from 1 to 5 or from 1 to 3 ).

The defined criteria (Table 1) in relation to which evaluation of the potential locations for constructing the terminal for waste from vessels in Belgrade was carried out, were based on:

$>$ requirements and recommendations of international and national documents in this field,

$>$ research and analysis of the practical experiences of other countries and recommendations of the EU, and the availability of relevant data for evaluation,

$>$ existing planning/urban documentation, 
predictions made regarding the types and quantities of ship-generated waste, that is, the required area for constructing the terminal,

$>$ data and information collected during visits to potential sites,

$>$ information available on the potential locations, and others.

Table 1. Criteria for selecting a location for the terminal for waste from vessels in Belgrade

\begin{tabular}{|c|c|c|c|}
\hline \multicolumn{4}{|c|}{ CRITERIA FOR SELECTING A LOCATION FOR THE TERMINAL } \\
\hline $\begin{array}{l}\text { 1. up to } 20 \text { acres, } \\
\text { 2. } 20 \text { to } 30 \text { acres, } \\
\text { 3. over } 30 \text { acres. }\end{array}$ & 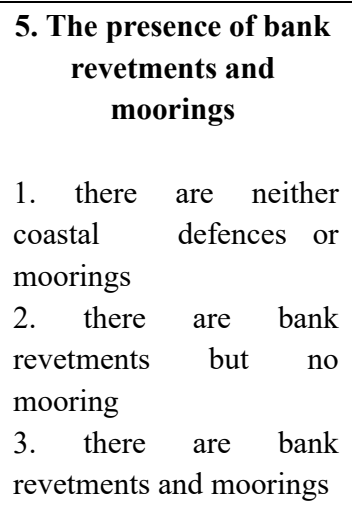 & $\begin{array}{l}\text { 1. } 100-300 \mathrm{~m} \\
\text { 2. }<100 \mathrm{~m} \\
\text { 3. There is a road with } \\
\text { satisfactory characteristics }\end{array}$ & $\begin{array}{l}\text { 1. levelling works required on the } \\
\text { majority of the location with the } \\
\text { necessary mechanization } \\
\text { 2. levelling required for a smaller part } \\
\text { of the location with the necessary } \\
\text { mechanization } \\
\text { 3. basic works on levelling the terrain } \\
\text { required for a small part of the } \\
\text { location }\end{array}$ \\
\hline $\begin{array}{l}\text { 2. Distance of } \\
\text { the location from } \\
\text { the waterway }\end{array}$ & $\begin{array}{l}\text { 6. } \begin{array}{l}\multicolumn{1}{c}{\begin{array}{c}\text { Relief of the } \\
\text { terrain }\end{array}} \\
\text { 1. }\end{array} \\
\begin{array}{l}\text { Non-compact spatial } \\
\text { unit }\end{array} \\
\text { 2. } \begin{array}{l}\text { compact spatial unit } \\
\text { formed naturally on }\end{array} \\
\text { steep terrain } \\
\text { 3. gently sloping or flat } \\
\text { terrain }\end{array}$ & $\begin{array}{l}\text { 10. Existing infrastructure } \\
\text { at the location } \\
\text { 1. there is no infrastructure at } \\
\text { all } \\
\text { 2. there is resolved primary } \\
\text { infrastructure } \\
\text { 3. there is resolved secondary } \\
\text { infrastructure }\end{array}$ & $\begin{array}{l}\text { 14. Market value of the undeveloped } \\
\text { construction land at the location } \\
\text { 1. zone I } \\
\text { 2. zone II } \\
\text { 3. zona III }\end{array}$ \\
\hline $\begin{array}{l}\text { 3. Distance of } \\
\text { the location along } \\
\text { the waterway from } \\
\text { an international } \\
\text { port for cargo } \\
\text { traffic } \\
\text { 1. over } 5 \mathrm{~km} \\
\text { 2. } 1-5 \mathrm{~km} \\
\text { 3. } \leq 1 \mathrm{~km}\end{array}$ & $\begin{array}{l}\begin{array}{l}\text { 7. Distance to the } \\
\text { nearest residential } \\
\text { buildings }\end{array} \\
\begin{array}{l}\text { 1. } \leq 250 \mathrm{~m} \\
\text { 2. } 250-500 \mathrm{~m} \\
\text { 3. } \text { over } 500 \mathrm{~m}\end{array}\end{array}$ & $\begin{array}{l}\text { 11. Ownership of the land } \\
\text { 1. } 100 \% \text { private ownership } \\
\text { 2. private and state ownership } \\
\text { of the land of about } 50 \% \\
\text { each } \\
\text { 3. } 100 \% \text { state ownership }\end{array}$ & $\begin{array}{l}\text { 15. Characteristics of the area } \\
\text { 1. The natural surroundings are } \\
\text { significantly altered by building the } \\
\text { terminal } \\
\text { 2. The natural surroundings are } \\
\text { insignificantly altered by building the } \\
\text { terminal } \\
\text { 3. The natural surroundings are } \\
\text { improved by building the terminal } \\
\text { (protective zone) }\end{array}$ \\
\hline $\begin{array}{l}\text { 4. Distance of } \\
\text { the location along } \\
\text { the waterway from } \\
\text { an international } \\
\text { port for tourist } \\
\text { traffic } \\
\text { 1. over } 5 \mathrm{~km} \\
\text { 2. } 1-5 \mathrm{~km} \\
\text { 3. } \leq 1 \mathrm{~km}\end{array}$ & $\begin{array}{l}\text { 8. Linear distance } \\
\text { from the nearest access } \\
\text { road } \\
\text { 1. over } 200 \mathrm{~m} \\
\text { 2. } 100-200 \mathrm{~m} \\
\text { 3. } \leq 100 \mathrm{~m}\end{array}$ & $\begin{array}{l}\text { 12. Current use of the land } \\
\text { 1. cultivated agricultural } \\
\text { land } \\
\text { 2. individual and other } \\
\text { buildings surrounding the } \\
\text { location } \\
\text { 3. undeveloped construction } \\
\text { land }\end{array}$ & $\begin{array}{l}\text { 16. Sanitary protection zone for the } \\
\text { water supply } \\
\text { 1. The location is in the narrow } \\
\text { sanitary protection zone } \\
\text { 2. The location is in the wider sanitary } \\
\text { protection zone } \\
\text { 3. The location is not in the sanitary } \\
\text { protection zone }\end{array}$ \\
\hline
\end{tabular}

It is possible to classify additional criteria in addition to the above, which could also be used to evaluate potential locations for the future construction of a terminal for boat waste (hydro-geological, geotechnical, geomechanical, etc.). However, the selection of criteria was based only on the data available on the locations, in order for the results obtained from the the evaluation to be objective. In this case, selection carried out in this way proved to be adequate. As shown, each criterion is evaluated with a score of 1 to 3 for each potential location. 


\subsubsection{Determination of the Weight Factors and Grouping of Criteria into Weight Categories}

After selecting the relevant criteria and defining the value scale for each criterion (scores from 1 to 3 ), the criteria were given appropriate weighted values. The criteria were classified according to their importance into 3 weight categories (WC). Each WC has its own specific value - the weight that is multiplied by the value of the criterion it belongs to. In this way a final score is obtained for each criterion. The specific values for the weight categories are:

$$
\begin{array}{ll}
> & \mathrm{WC} 1=1 \\
> & \mathrm{WC} 2=1.5 \\
> & \mathrm{WC} 3=3
\end{array}
$$

\begin{tabular}{|c|c|c|}
\hline WC 3 & WC 2 & WC 1 \\
\hline 1. Space available for locating the terminal & 6. Relief of the terrain & $\begin{array}{l}\text { 9. Service (access road) - } \\
\text { construction }\end{array}$ \\
\hline Distance of the location from the waterway & $\begin{array}{l}\text { 7. Distance to the nearest } \\
\text { residential buildings }\end{array}$ & 11. Ownership of the land \\
\hline $\begin{array}{l}\text { 3. Distance of the location along the waterway } \\
\text { from an international port for cargo traffic }\end{array}$ & $\begin{array}{l}\text { 8. Linear distance from the } \\
\text { nearest access road }\end{array}$ & 12. Current use of the land \\
\hline \multirow{3}{*}{$\begin{array}{l}\text { 4. Distance of the location along the waterway } \\
\text { from an international port for tourist traffic } \\
\text { The presence of bank revetments and } \\
\text { moorings }\end{array}$} & $\begin{array}{l}\text { 10. Existing infrastructure } \\
\text { at the location }\end{array}$ & $\begin{array}{l}\text { 14. Market value of the undeveloped } \\
\text { construction land at the location }\end{array}$ \\
\hline & $\begin{array}{l}\text { 13. Development of the } \\
\text { terrain }\end{array}$ & 15. Characteristics of the area \\
\hline & $\begin{array}{l}\text { 16. Sanitary protection zone } \\
\text { for the water supply }\end{array}$ & \\
\hline
\end{tabular}

Between the weight categories, the following applies: $\mathrm{K}_{\mathrm{i}+1}=\mathrm{K}_{\mathrm{i}} / 1.5$

Table 2. Grouping the criteria according to weight categories (WC)

\subsubsection{Multi-Criteria Evaluation of the Potential Locations According to the Weight Categories}

The principle of multi-criteria evaluation of the potential locations according to weight categories is presented in

\begin{tabular}{|c|c|c|c|c|c|}
\hline Criteria & WC & PL1 & PL2 & PL3 & PL4 \\
\hline 1. Space available for locating the terminal & WC 3 & 9 & 9 & 9 & 9 \\
\hline 2. Distance of the location from the waterway & WC 3 & 6 & 6 & 9 & 6 \\
\hline $\begin{array}{l}\text { 3. Distance of the location along the waterway from an international port for cargo } \\
\text { traffic }\end{array}$ & WC 3 & 3 & 3 & 9 & 3 \\
\hline $\begin{array}{l}\text { 4. Distance of the location along the waterway from an international port for tourist } \\
\text { traffic }\end{array}$ & WC 3 & 3 & 3 & 6 & 3 \\
\hline 5. The presence of bank revetments and moorings & WC 3 & 3 & 3 & 6 & 3 \\
\hline 6. Relief of the terrain & WC 2 & 1.5 & 3 & 4.5 & 4.5 \\
\hline 7. Distance to the nearest residential buildings & WC 2 & 4.5 & 1.5 & 4.5 & 3 \\
\hline 8. Linear distance from the nearest access road & WC 2 & 4.5 & 4.5 & 4.5 & 4.5 \\
\hline 10. Existing infrastructure at the location & WC 2 & 1.5 & 1.5 & 3 & 3 \\
\hline 13. Development of the terrain & WC 2 & 1.5 & 1.5 & 4.5 & 3 \\
\hline 16. Sanitary protection zone for the water supply & WC 2 & 4.5 & 4.5 & 4.5 & 1.5 \\
\hline 9. Service (access road) - construction & WC 1 & 1 & 1 & 1 & 2 \\
\hline 11. Ownership of the land & WC 1 & 2 & 1 & 3 & 3 \\
\hline 12. Current use of the land & WC 1 & 1 & 2 & 3 & 3 \\
\hline 14. Market value of the undeveloped construction land at the location & WC 1 & 3 & 3 & 1 & 2 \\
\hline 15. Characteristics of the area & WC 1 & 2 & 2 & 3 & 3 \\
\hline \multicolumn{2}{|l|}{ Total sum of the values of the individual criteria } & 51.0 & 49.5 & 75.5 & 56.5 \\
\hline
\end{tabular}
Table 3.

Table 3. Evaluation of the potential locations (PL) according to the chosen criteria

The scores of the criteria (1-3) were multiplied with the specific values for each of the 15 criteria, and in that way the values were obtained that are presented in Table 3. Simply by adding the values for each criterion, a total 
score was obtained for each potential location. As a result of the evaluation of the locations according to weight categories, the most favorable location was seen to be PL3, after which the locations were in the following order: PL4, PL1 and in last place PL2. The most important advantages of PL3 (the Port of Belgrade) over the other potential locations are:

$>$ Proximity of the location to an international port for cargo traffic,

$>$ Proximity of the location to an international port for tourist traffic,

$>$ The presence of bank revetments,

$>$ The relief of the terrain,

$>$ arrangement of the terrain,

$>$ existing infrastructural facilities.

3.2.4 Evaluation of the Potential Sites Under Different Scenarios

When evaluating the potential locations under different scenarios, based on the PROMETHEE method, the criteria chosen for selecting the location were sorted into primary groups, and in the evaluation, for each individual scenario criteria from one of the primary groups were favored. As the final option, the case was considered in which the groups of criteria were multiplied by the same score of importance, without favoring any particular group of criteria. This scenario has as many criteria as the other groups, plus one for the scenario in which each group of basic criteria is evaluated equally.

The chosen criteria for evaluating the potential locations of the terminal for waste from vessels in Belgrade under different scenarios were classified into three main groups (Table 4).

Table 4. Classification of the chosen criteria in the basic groups of criteria

\begin{tabular}{|c|c|c|}
\hline ENVIRONMENTAL & SOCIAL & ECONOMIC \\
\hline 6. Relief of the terrain & $\begin{array}{l}\text { 7. Distance to the nearest } \\
\text { residential buildings }\end{array}$ & 1. Space available for locating the terminal \\
\hline 13. Development of the terrain & 11. Ownership of the land & Distance of the location from the waterway \\
\hline 15. Characteristics of the area & 12. Current use of the land & $\begin{array}{l}\text { 3. Distance of the location along the waterway } \\
\text { from an international port for cargo traffic }\end{array}$ \\
\hline \multirow[t]{6}{*}{$\begin{array}{l}\text { 16. Sanitary protection zone for the } \\
\text { water supply }\end{array}$} & & $\begin{array}{l}\text { 4. Distance of the location along the waterway } \\
\text { from an international port for tourist traffic }\end{array}$ \\
\hline & & 5. The presence of bank revetments and moorings \\
\hline & & 8. Linear distance from the nearest access road \\
\hline & & 9. Service (access road) - construction \\
\hline & & 10. Existing infrastructure at the location \\
\hline & & $\begin{array}{l}\text { 14. Market value of the undeveloped construction } \\
\text { land at the location }\end{array}$ \\
\hline
\end{tabular}

The score of each individual criterion from the primary evaluation is multiplied by the weight values for the groups of criteria according to different scenarios. The weight values in this case are percentage values, the total sum of which is $100 \%$, with the largest percentage value given to the group of criteria favored in the given scenario (Table 5).

Table 5. The weight values for the primary groups of criteria in scenarios

\begin{tabular}{lccccc}
\hline $\begin{array}{l}\text { Basic groups } \\
\text { of criteria }\end{array}$ & Scenario & SC 1 & SC 2 & SC 3 & SC 4 \\
\hline ENVIRONMENTAL & & $\mathbf{0 . 5 0}$ & 0.25 & 0.25 & $\mathbf{0 . 3 3}$ \\
SOCIAL & 0.25 & $\mathbf{0 . 5 0}$ & 0.25 & $\mathbf{0 . 3 3}$ \\
ECONOMIC & 0.25 & 0.25 & $\mathbf{0 . 5 0}$ & $\mathbf{0 . 3 3}$ \\
\hline
\end{tabular}

After multiplying the values of the criteria from the primary evaluation with the weighted criteria according to the different scenarios and their simple sum, ranking was obtained for the locations for the terminal for waste from vessels according to the different scenarios (Tables 6). 
Table 6. Ranking of the potential locations according to different scenarios

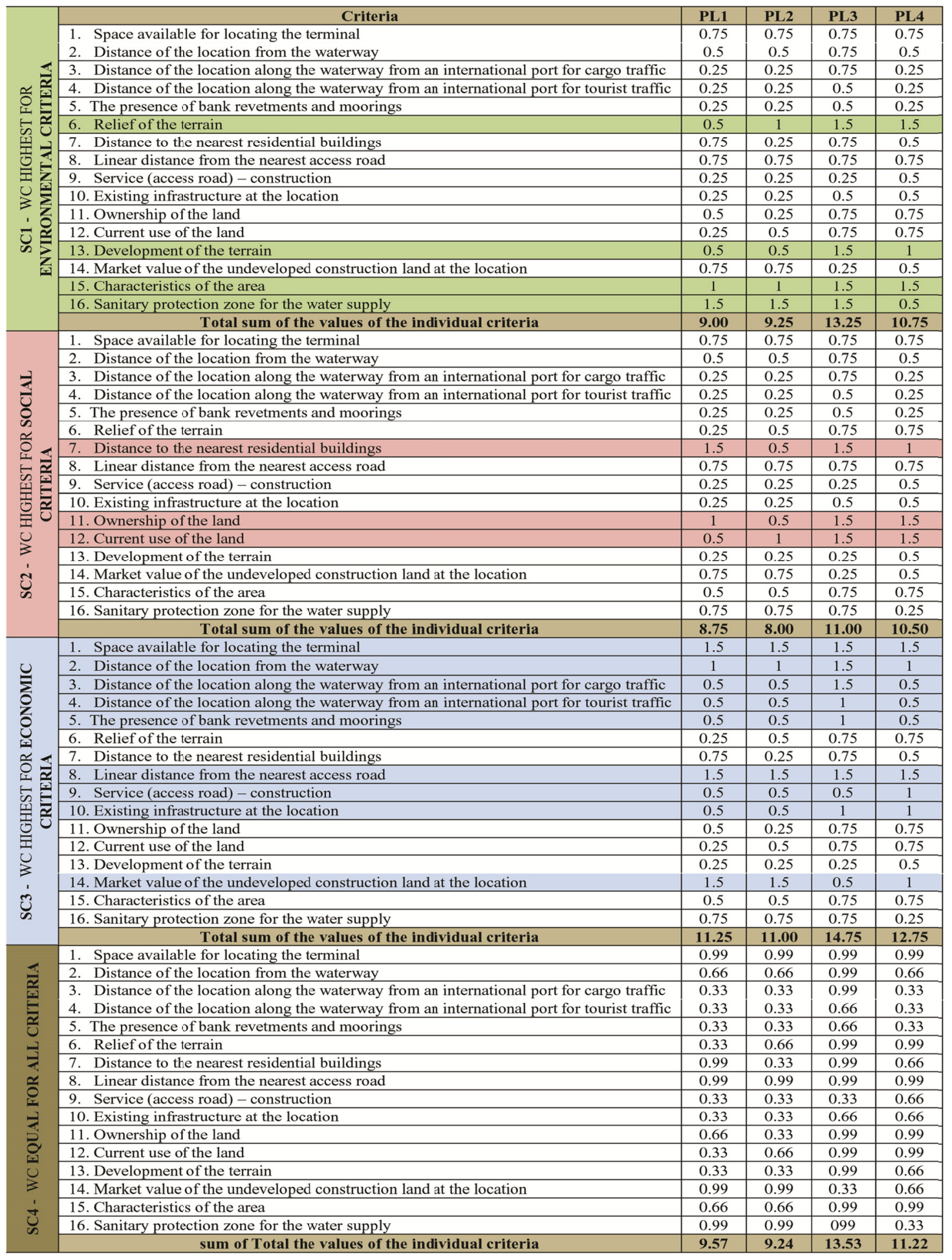

Table 7. A synthesis presentation of the potential locations according to the different scenarios

\begin{tabular}{|c|c|c|c|c|}
\hline \multirow{2}{*}{ Scenario } & SC 1 & $\mathrm{SC} 2$ & SC 3 & $\mathrm{SC} 4$ \\
\hline & \multicolumn{4}{|c|}{ Ranking of the locations } \\
\hline \multirow{4}{*}{ Potential locations } & PL3 & PL3 (11.00) & PL3 (14.75) & PL3 (13.53) \\
\hline & PL4 (10.75) & PL4 (10.50) & PL4 (12.75) & PL4 (11.22) \\
\hline & PL2 (9.25) & PL1 (8.75) & PL1 (11.25) & PL1 (9.57) \\
\hline & PL1 (9.00) & PL2 (8.00) & PL2 (11.00) & PL2 (9.24) \\
\hline
\end{tabular}


Multi-criteria evaluation of all of the scenarios confirmed the results obtained by evaluating the potential locations according to the chosen criteria and weight categories. Thus, location PL3 showed the best values according to each of the scenarios. Location PL4 takes second place for all of the categories, while the remaining potential locations take different positions depending on the scenario.

\subsubsection{Recapitulation of the Evaluation Indicating the Best Locations}

On the basis of the comparative multi-criteria evaluation of the potential locations, the most important advantages and disadvantages of the candidate locations were identified (Table 8).

Table 8. The most important advantages and disadvantages of the potential locations

\begin{tabular}{|c|c|}
\hline Advantages & Disadvantages \\
\hline \multicolumn{2}{|r|}{ Potential location 1 (PL1) } \\
\hline $\begin{array}{l}\text { - Large space available } \\
\text { - Distance from residential buildings } \\
\text { - Proximity of access roads } \\
\text { - Market value of the undeveloped } \\
\text { construction land }\end{array}$ & $\begin{array}{l}\text { - Large distance from the international port for cargo traffic }(11 \mathrm{~km}) \\
\text { - Large distance from the international port for tourist traffic }(10.5 \mathrm{~km}) \\
\text { - There are no revetments or moorings } \\
\text { - Unfavorable characteristics of the relief (on the loess terrace in the } \\
\text { delevelling with the Danube River about } 20 \mathrm{~m}) \\
\text { - Ownership relations (private and state) }\end{array}$ \\
\hline \multicolumn{2}{|r|}{ Potential location 2 (PL2) } \\
\hline $\begin{array}{l}\text { - Large space available } \\
\text { - Proximity of access roads } \\
\text { - Market value of the undeveloped } \\
\text { construction land }\end{array}$ & $\begin{array}{l}\text { - Large distance from the international port for cargo traffic }(9 \mathrm{~km}) \\
\text { - Large distance from the international port for tourist traffic }(8.5 \mathrm{~km}) \\
\text { - There are no revetments or moorings } \\
\text { - Unfavorable characteristics of the relief (on the loess terrace in the } \\
\text { delevelling with the Danube River about } 20 \mathrm{~m}) \\
\text { - Proximity to residential buildings } \\
\text { - Ownership relations (private) }\end{array}$ \\
\hline \multicolumn{2}{|r|}{ Potential location 3 (PL3) } \\
\hline $\begin{array}{l}\text { - Large space available } \\
\text { - Proximity of access roads } \\
\text { - Proximity of the international port for } \\
\text { cargo transport }(500 \mathrm{~m}) \\
\text { - Proximity of the international port for } \\
\text { tourist transport }(3.5 \mathrm{~km}) \\
\text { - Presence of revetments } \\
\text { - Configuration of the terrain } \\
\text { - Good infrastructure at the location } \\
\text { - Few interventions to develop the terrain } \\
\text { - Distance from residential buildings } \\
\text { - Ownership relations (state-City of } \\
\text { Belgrade) }\end{array}$ & $\begin{array}{l}\text { - There are no revetments } \\
\text { - High market value of the construction land } \\
\text { - Uncertainty regarding compatability with the plans for expanding the } \\
\text { district heating }\end{array}$ \\
\hline \multicolumn{2}{|r|}{ Potential location 4 (PL4) } \\
\hline $\begin{array}{l}\text { - Large space available } \\
\text { - Proximity of access roads } \\
\text { - Configuration of the terrain } \\
\text { - Good infrastructure } \\
\text { - Few interventions to develop the terrain } \\
\text { - Ownership relations (state) }\end{array}$ & $\begin{array}{l}\text { - Large distance from the international port for cargo traffic (about } 9 \mathrm{~km}) \\
\text { - Large distance from the international port for tourist traffic (about } 5 \mathrm{~km}) \\
\text { - There are no revetments or moorings } \\
\text { - High market value of the construction land } \\
\text { - Proximity to residential buildings } \\
\text { - Located in the narrow zone of protection for water supply sources. }\end{array}$ \\
\hline
\end{tabular}

To sum up the results of the evaluation, it was concluded that all of the locations have certain advantages and disadvantages (Table 8), and that none of the potential locations for the construction of a terminal for waste from vessels in Belgrade are ideal as they do not meet all of the necessary requirements. However, in all of the presented variants and evaluation scenarios, potential location PL3 (Port of Belgrade) had the best results compared to the three other potential locations, so in this context it can be concluded that it is the most favorable for the location and construction of a terminal for waste materials from vessels. 
Also, only PL3 meets the international requirements/recommendations regarding the location of a terminal for waste from vessels within a port with international status, and thus in this way it provides rationality in the collection and transport of waste to the terminal. In addition, the site is situated within the Port of Belgrade (Figure 3), which is located at the intersection of two Pan-European transport corridors (river VII and road X) and it is the traffic, transloading and goods transport crossroads of Central Europe. It is a port of international significance with a cargo center and passenger dock.

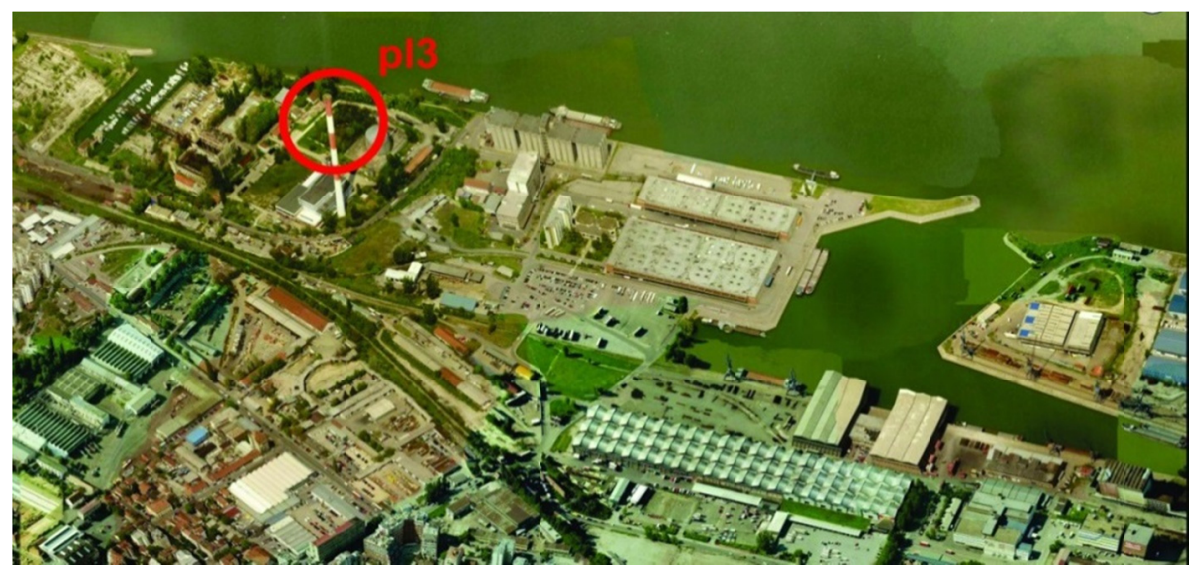

Figure 3. PL 3 on orthophoto footage

In the context of the given facts, the recommendation was given to the decision makers that this location should be chosen as the most favorable.

\section{Discussion and Conclusions}

The results of this comparative multi-criteria evaluation in combination with the PROMETHEE method of evaluation by different scenarios enabled decision makers to be presented with different arguments and insights into the environmental, spatial, social and economic implications of making a decision regarding the selection of the most favorable location for a terminal for waste from vessels in Belgrade. This is precisely the essence of the methodological approach applied here.

In this case study, in all of the variations for evaluating the potential locations, one location (PL3) was the most favorable, so in this context it was not difficult to select this location. The Decision on the choice of location PL3 was passed by the City Administration of Belgrade, on the basis of the results that are presented in this paper, and in consultation with the Ministry of Agriculture and Environmental Protection, the Public Company Serbia Water, the Harbor Master, and the Agency for managing ports. When making the decision, the obligations and recommendations from relevant international documents and agreements were taken into account: the MARPOL Convention on measures to prevent pollution of rivers and the sea with waste from ships; European Agreement concerning the International Carriage of Dangerous Goods by Inland Waterways (ADN); Strasbourg Convention on Limitation of Liability in Inland Navigation (CLNI Convention); EU Directive on ports 2000/59/EC; etc.

The methodological approach presented here may have broad application in the selection of locations for different facilities and projects, with the criteria and scenarios under consideration being adapted to each particular case. Its application offers decision makers the possibility of making the most optimal decisions, and that is its quality.

However, as with many methods for multi-criteria evaluation that are in use, there is the question of the objectivity of the process, considering that the selection of elements for evaluation (criteria, groups of criteria, weighted values, etc.), and indeed the process of decision making itself is a matter of the subjectivity of experts and decision makers. That can be considered as the universal drawback of this and similar methods, so the subjectivity in this process should be minimized, and the objectivity maximized. One of the possibilities for the implementation of this approach is the formation of a multidisciplinary team that participates in designing basic methodological procedures, in order to examine the approach to a problem from its different aspects. This was exactly the case in the writing of this paper, and also in the presentation of the case study.

\section{Acknowledgment}

This paper is a result of a research conducted as part of the scientific project themed "Sustainable spatial 
development of Danubian Serbia", TR36016, financed by the Ministry of Education, Science and Technological Development of the Republic of Serbia in 2011-2016.

\section{References}

Ananda, J., \& Heralth, G. (2009). A critical review of multi-criteria decision-making methods with special reference to forest management and planning. Ecological Economics, 68(10), 2535-2548.

Banville, C., Landry, M., Martel, J. M., \& Boulaire, C. (1998). A stakeholder approach to MCDA. Systems Research and Behavioral Science, 15(1), 15-32.

Behzadiana, M., Kazemzadehb, R. B., Albadvib, A., \& Aghdasib, M. (2010). PROMETHEE: A comprehensive literature review on methodologies and applications. European Journal of Operational Research, 200, 198215.

Brans, J. P., \& Vincke, P. H. (1984). Preference Ranking Organisation Method for Enrichment Evaluations - The Promitee Method for Multiple Criteria Decision Making. Centrum voor Statistiek en Oparatineel Onderzoek, Vrije Universiteit, Brussel.

CL:AIRE. (2011). Annex 1: The SuRF-UK indicator set for sustainable remediation assessment. London. Convention on the Danube River Navigation Regime Official Gazette FPRY. No. 8/49, Official Gazette FRY, International agreements, No. 6/98.

CO-WANDA. (2014). Transnational network of ship waste reception facilities along the Danube, 15-16, 40-41.

De Marchi, B., Funtowicz, O., Lo Cascio, S., \& Munda, G. (2000). Combining participative and institutional approaches with multicriteria evaluation. An empirical study for water issues in Troina, Sicily. Ecological Economics, 34, 267-282.

Directive on ports. 2000/59/EC. (2000). European parliament. European Agreement on the International Carriage of Dangerous Goods by Inland Waterways. (ADN) Official Gazette RS- International agreements, number $3 / 10$.

Figueira, J., Greco, S., \& Ehrgott, M. (2005). Multiple-criteria decision analysis. State of the Art Surveys. Springer, New York. General Urban Plan (GUP) of Belgrade to 2021. Official Gazette of the city of Belgrade, No. 25/05, 34/07, 63/09 and 70/14.

Josimović, B., Marić, I., \& Milijić, S. (2015). Multi-Criteria Evaluation in Strategic Environmental Assessment for Waste Management Plan, A Case Study: The City of Belgrade. Waste Management Journal, 36, 331-342. http://dx.doi.org/10.1016/j.wasman.2014.11.003

Kangas, J., \& Kangas, A. (2005). Multiple criteria decision support in forest management the approach-methods applied, and experiences gained. Forest Ecology and Management, 207, 133-143.

Linkov, I., Satterstrom, F. K., Kiker, G., Batchelor, C., Bridges, T., \& Ferguson, E. (2006). From comparative risk assessment to multi-criteria decision analysis and adaptive management: recent developments and applications. Environ, Risk, Manag, 32, 1072-93.

MARPOL. (1973). International Convention for the Prevention of Pollution from Ships.

Munda, G. (2005). Multiple criteria decision analysis and sustainable development. In: Figueira, J, Salvatore, G, Ehrgott, M. (Eds.), Multiple Criteria Decision Analysis: State of the Art Surveys. Springer, New York.

Munda, G. (2008). Social Multi-criteria Evaluation for Sustainable Economy. Springer, New York.

Proctor, W. (2004). MCDA and stakeholder participation - valuing forest resources. In: Getzner, M., Spash, C. L., Stagl, S. (Eds.), Alternatives for Environmental Valuation. Routledge, London, 134-158.

Proctor, W., Drechsler, M., 2006. Deliberative multicriteria evaluation. Environment and Planning C: Government and Policy, 24, 169-190.

Rosén, L., Back, P. E., Norrman, J., Söderqvist, T., Brinkhoff, P., \& Volchko, Y. (2013). Multi-criteria analysis (MCA) for sustainability appraisal of remedial alternatives. Proceedings of the Second International Symposium on Bioremediation and Sustainable Environmental Technologies. Jacksonville, Florida, USA.

Rosén, L., Söderqvist, T., Back, P. E., Soutukorva, Å., Brodd, P., \& Grahn, L. (2009). Mulicriteria analysis (MCA) for sustainable remediation at contaminated sites. Method development and examples. Swedish: Multikriterieanalys (MKA) för hållbar efterbehandling av förorenade områden. Metodutveckling och exempel. Sustainable Remediation Programme, Report 5891 Stockholm: Swedish Environmental Protection Agency. 
Roy, B. (1985). Méthodologie multicritere d' aide à la decision. Economica, Paris.

Simon, E. (1976). From substantive to procedural rationality. In: Latsis, J. S. (Ed.), Methods and Appraisal in Economics. Cambridge University Press, Cambridge.

Sparrevik, M., Barton, D. N., Bates, M. E., \& Linkov, I. (2011). Use of stochastic multi-criteria decision analysis to support sustainable management of contaminated sediments. Environ. Sci. Technol, 46, 1326-34.

Zionts, S. (1979). MCDM-if not a Roman numeral, then what? Interfaces, 9, 94-101.

Zionts, S., \& Wallenius, J. (1976). An interactive programming method for solving the multiple criteria problem. Management Science, 22, 652-663.

\section{Copyrights}

Copyright for this article is retained by the author(s), with first publication rights granted to the journal.

This is an open-access article distributed under the terms and conditions of the Creative Commons Attribution license (http://creativecommons.org/licenses/by/3.0/). 